Malherbe BR \& Hendriks $E$

\title{
AN INVESTIGATION INTO THE DETERMINANTS OF JOB SATISFACTION AND THE IMPROVEMENT OF QUALITY OF WORK LIFE OF GRASSROOTS SOCIAL WORKERS
}

Dr Blanche R Malherbe is the Head of the Department of Social Work at the Huguenot College Wellington and Mrs Elma Hendriks is a Programme Manager at the Society for the Physically Disabled, Cape Town.

\section{BACKGROUND TO THIS STUDY}

It is often simply assumed that social workers experience job satisfaction because it is assumed that people who choose this profession do so for altruistic reasons (King \& Botha 1997:107). The consequence of the lack of job satisfaction among social workers is poor quality of work and this in turn has a negative impact on their physical health, mental health and social functioning (Vinokur-Kaplan, Jayarentne \& Chess, 1994:95).

Silver, Poulin and Manning (1997:3) state that, although the concept of job satisfaction receives a lot of attention in the literature in, among other fields, social psychology and human resource management, it is only recently that researchers began focusing on the job satisfaction of social workers.

Writers such as Skidmore, Thackeray and Farley (1997:363) also point to the changes that social work management has undergone. According to them, in the past the administration of welfare organisations was based on a hierarchical system with a director, assistant director, supervisor and staff, with all the power vested in the director. Kadushin (1992:253) is of the opinion that this sort of highly formalised hierarchical system and extensive rules and regulations can be associated with burnout of social workers and a lack of job satisfaction. In the more recent past huge changes took place and power is no longer based at the top of the hierarchical system, but is shared in an interactive circle: authority, planning and decision-making power are shared by the administrator, staff and clients. In this circle the satisfaction of the client and job satisfaction of the social worker are formidable forces that must be taken into account.

There are, however, certain preconditions that will have to be met if welfare organisations are to prosper in this changing environment. Wiesner and Vermeulen's (1997:175) opinion regarding these preconditions is that organisations must provide their personnel with a high quality of work life and they must be highly adaptable in their functioning.

Carrell, Elbert, Hatfield, Grobler, Marx and Van der Schyf (1998:558, 570) are of the opinion that people - with all their problems - remain the most important resource of any organisation. Personnel problems that the social work manager may experience are high levels of absenteeism and staff turnover, regular complaints, low morale, poor attitude to the work as well as resistance to change, job dissatisfaction and perceptions of unfairness. Without a future perspective on how to address these problems, welfare organisations will remain reactive instead of responding proactively. Job satisfaction and reduced staff turnover are some of the critical challenges that social work managers face, because the consequences of staff turnover are expensive and have a negative influence on clients. In the literature on Business Economics much attention is given to, among other things, the job satisfaction of personnel. The question is whether or not social work managers use this knowledge of job satisfaction for the benefit of grassroots social workers. 
The primary problem for managers therefore remains the need to increase job satisfaction so as to improve the quality of services delivered by the grassroots social workers to the client system and to minimise the cost of absenteeism and staff turnover. Cost effectiveness is becoming ever more important to welfare organisations in South Africa, where financing from the state coffers is becoming increasingly reduced and diversified.

\section{RESEARCH GOALS}

The goals of the study were to provide a scientifically founded framework of the determinants of job satisfaction for grassroots social workers and to highlight the programmes that can be implemented to address this issue.

In order to achieve this goal, the objectives of this study were as follows:

- To identify and describe what the determinants of job satisfaction for grassroots social workers are;

- To explore and describe how the issue of job satisfaction can be addressed by the supervisor;

- To explore and describe which of the components of good quality of work life are of

- importance to grassroots social workers; and

- To explore and describe which programmes aimed at improving the quality of work life of grassroots social workers can be applied.

\section{RESEARCH PLAN}

\section{Research design}

A study was made of applicable and available American, British and South African literature. Due to the fact that the variables job satisfaction, job dissatisfaction and quality of work life receive little attention in social work literature, the literature study was expanded to include organisational management, human resource management and industrial psychology.

This is mainly an explorative and descriptive study. Exploratory research was considered as relatively little research has been done on the management of job satisfaction in social work. Only Snyman's (1990) research focuses on the role of management in the improvement of quality of work life and productivity. Theron's (1995) research deals with the role of supervision with regard to the job satisfaction of social workers, while King \& Botha's (1997) research highlights the organisational determinants of job satisfaction in social work.

\section{Sampling and ways of gathering data}

The unit of analysis was grassroots social workers at the Society for the Physically Disabled in the Western Cape Region who render a direct service to clients and who are not in a supervisory or management post. Poulin (1995:35) quotes various studies (Haynes, 1979; Jayaratne \& Chess, 1984; Barber, 1986) in which it was found that social workers who deliver a direct service have a different perspective as to what aspects lead to job satisfaction than do those in middle and/or top management positions.

Twenty two grassroots social workers employed by the Western Cape Society for the Physically Disabled were included in this study so as to gain as representative an image as possible of the job satisfaction of the welfare organisation's social workers in this region. A preliminary investigation that was done by means of a questionnaire in December 1999 had already revealed that personal 
determinants such as self-image, age qualifications, length of service and marital status do not play a significant role in the job satisfaction of social workers, but that organisational determinants such as work content, opportunities for promotion and leadership and management style do. The survey method was used for the purposes of gathering data. A structured self-reporting questionnaire was designed based on the literature study and was subjected to preliminary testing.

\section{DESCRIBING AND DEFINING THE TERM JOB SATISFACTION}

Job satisfaction concerns a personnel member's (in this case a social worker's) attitude or emotional disposition to his/her work. Job satisfaction is increased by a manager's ability (in this case, the manager of a welfare organisation) to make work satisfying and to overcome those obstacles that prevent effective service delivery by social workers. Although job satisfaction is not equal to motivation, job satisfaction is nevertheless necessary to ensure high levels of motivation and achievement (Mullins, 1999:629).

The terms "job satisfaction" and "career satisfaction" are used interchangeably by writers such as Van der Westhuizen, Wissing and Hillebrand (1992:40), King and Botha (1997:107,108) and Nel (1998:141). For the purposes of this investigation the term job satisfaction was used.

During Van Niekerk's (1994:180) research, which was completed in 1994, it was found that there are various operational definitions of job satisfaction. Her opinion is that in 1976 Locke had already formulated a generally accepted definition, namely that job satisfaction is a pleasant and positive emotional disposition, which flows from how the personnel's work or working experience is rated. More recent writers such as Conway, Williams and Green (1987:48), Theron (1995:7), Gibson, Ivancevich and Donelly $(1997: 42,106)$, Robbins $(1998: 25,142,151)$ and Carrell et al. (1998:511) agree to a large extent that job satisfaction is an individual's attitude or feeling of satisfaction with regard to his/her work and role within the organisation. Different authors' definitions highlight various aspects that play a role in job satisfaction:

- Job satisfaction, according to (Conway et al. 1987:48) is generally experienced as a feeling or affective state, which personnel experience with regard to their work;

- According to Mumford (1991) as quoted by Mullins (1999:662), job satisfaction is a fit between the organisations' requirements, what the social worker expects and that which the social worker receives;

- For King \& Botha (1997:109) job satisfaction is a positive or negative emotional reaction of an individual that is based on his/her experience of the extent to which his/her personal needs and goals correspond to or differ from the rewards that the organisation or profession offers and the expectations that it sets;

- Robbins (1998:142) is of the opinion that job satisfaction refers to an individual's general attitude towards his work;

- Finally, Mullins (1999:661) regards job satisfaction as an emotion, a feeling, an attitude and a matter of perceptions.

Writers such as Conradie (1990:67), Poulin (1995:35) and Mullins (1999:630) describe job satisfaction as a multidimensional concept, which has different meanings for different individuals. They are of the opinion that there is an inter-woven relationship between all the facets that exert an influence on job satisfaction and that these facets cannot be separated from one another. 
FIGURE 1

A SCHEMATIC PRESENTATION OF THE CORE ELEMENTS OF JOB SATISFACTION

\begin{tabular}{|c|c|}
\hline $\begin{array}{l}\text { PERSONNEL } \\
\text { (What the personnel member expects) } \\
\text { A positive emotional disposition } \\
\text { A general attitude of satisfaction with } \\
\text { regard to the work } \\
\text { A general feeling of satisfaction with } \\
\text { regard to the role within the } \\
\text { organisation }\end{array}$ & $\begin{array}{l}\text { WORKING ENVIRONMENT } \\
\text { (What the work situation should be } \\
\text { like) } \\
\text { Appropriate recognition } \\
\text { Work must be challenging, stimu lating } \\
\text { and/or mean ingful } \\
\text { Facets of work that play a role are: } \\
\text { - The nature of the work itself } \\
\text { - The relationship with co-workers } \\
\text { - The nature of supervision } \\
\text { - The culture in the organ is ation } \\
\text { - The opportunity to grow }\end{array}$ \\
\hline \multicolumn{2}{|c|}{$\begin{array}{c}\text { RESULT } \\
\text { (Extent of job satisfaction or job dissatisfaction) }\end{array}$} \\
\hline
\end{tabular}

Job satisfaction consists of certain core elements, namely the attitude of the personnel member that flows out of the work situation, which in turn produces certain results. In 1997 King and Botha (1997:109) had already made the deduction that, from a process theory perspective, the development of job satisfaction and job dissatisfaction can be explained on the basis of the individual's comparisons of his/her work-related expectations. The latter interacts with various characteristics of the professional and working environment to determine the ultimate extent of job satisfaction. Figure 1 provides a schematic presentation of the care elements of job satisfaction.

Respondents' categorised responses to the open question: how they would define job satisfaction, are provided in Table 1. 
TABLE 1

ELEMENTS WITH REGARD TO THE DEFINITION OF JOB SATISFACTION

\begin{tabular}{|l|l|c|c|}
\hline & \multicolumn{1}{|c|}{ f } & $\%$ \\
\hline 1 & $\begin{array}{l}\text { A generally positive attitude of satisfaction and happiness within the } \\
\text { work situation }\end{array}$ & 14 & 64 \\
\hline 2 & $\begin{array}{l}\text { Space for personal and professional growth in an atmosphere in } \\
\text { which initiative can be taken }\end{array}$ & 11 & 50 \\
\hline 3 & $\begin{array}{l}\text { A competitive and fair remuneration package that leads to } \\
\text { professional pride }\end{array}$ & 8 & 36 \\
\hline 4 & Security and stability in the working environment & 5 & 23 \\
\hline 5 & Opportunities for promotion & 4 & 18 \\
\hline 6 & Recognition and motivation from the employer & 4 & 18 \\
\hline 7 & Good management style & 2 & 9 \\
\hline 8 & Professional inputs that produce positive results & 2 & 9 \\
\hline 9 & Co-operation with and acknowledgement from clients & 1 & 5 \\
\hline 10 & Sufficient resources and acknowledgement in the community & 1 & 5 \\
\hline 11 & A balanced professional life & 1 & 5 \\
\hline 12 & A safe working environment & & 5 \\
\hline
\end{tabular}

1. $\mathrm{n}=22$

2. Respondents could select more than one response.

The majority of the respondents are of the opinion that a generally positive attitude of satisfaction and happiness within the work situation define job satisfaction. This correlates with the definition of job satisfaction provided by Locke (1976) as quoted by Van Niekerk (1994:18).

\section{THE DETERMINANTS OF JOB SATISFACTION}

The literature study reveals that factors on an organisational, personal, social or group level interact with one another to influence the social worker's job satisfaction (Gruneberg, 1979; Arches, 1991 as quoted by King \& Botha, 1997:108). Butler's (1990:112) and Arches's (1991:202204) finding is that social workers' measure of job satisfaction is determined in particular by organisational factors. Poulin and Walter (1992:111) found that organisational factors can be more easily manipulated or changed than personal or other determinants. In this investigation the emphasis is therefore placed on organisational variables, although group variables were briefly touched on.

\section{Organisational variables}

Various organisational variables mentioned by writers, are grouped together in the following sections, namely work content, remuneration, opportunities for promotion, working environment, leadership and management style and group factors. 


\section{Work content}

Work content that is associated with job satisfaction is of such a nature that it stimulates social workers' interest, provides them with joy, develops their skills because there is a measure of complexity and a certain degree of difficulty associated with it, and they are given the opportunity to learn (Barber, 1986:26; King \& Botha, 1997:109). In its totality the work must be challenging. When social workers are offered the opportunity to be creative and to do increasingly more responsible work, they experience satisfaction with their work (Corlett, 1979; Chetty, 1983 as quoted by King \& Botha, 1997:109). Task diversity, which implies that a variety of skills are utilised in performing daily tasks as well as the meaningfulness of tasks, creates greater satisfaction (Barber, 1986:26; Himle, 1986; London \& Mone, 1987; Butler, 1990, as quoted by King \& Botha, 1997:109).

King and Botha's (1997:109) investigation in 1997, which involved a hundred randomly selected social workers in the Free State, revealed that social workers experienced their work content as positive with regard to its variety and the opportunity to be creative. Respondents therefore placed a high premium on the challenge and meaningfulness of work content as determinants of job satisfaction. Out of eleven possible determinants of job satisfaction, the above-mentioned respondents assigned the highest priority to work content.

\section{Remuneration}

Snyman (1990:79) states that for most people remuneration is the driving force behind why they work and that social workers also expect to be adequately and fairly remunerated.

King and Botha's (1997:111) research reveals that social workers are dissatisfied with their remuneration and are no longer prepared to work simply for the good of the cause. The influence that dissatisfaction with salaries has on social workers' overall job satisfaction is confirmed in their investigation during which respondents assigned the third highest priority to a good salary and benefits as a requirement for overall job satisfaction from a list of eleven factors that influence job satisfaction.

\section{Opportunities for promotion}

The statement has been made that personnel have a need to experience their growth and development. Haldene (1974) as quoted by King and Botha (1997:112) found that there are few to no promotional opportunities available in the social work profession. He states that it can be argued that the profession is in danger of losing ambitious and dynamic personnel because of poor opportunities for promotion, while it is in fact these staff members that should be kept.

\section{Working environment}

Working environment includes physical components as well as the psycho-social atmosphere. Barber (1986:27) is of the opinion that the working environment also includes aspects of work security for social workers. Aspects such as a warm friendly atmosphere, support, constructive conflict management, reasonable conditions of service and group loyalty are also linked to job satisfaction.

\section{Leadership and management style}

Writers such as Glisson and Durrick (1988) quoted by Poulin (1995:36) found that satisfaction with leadership in which the supervisor is also included contributes to a large extent towards job satisfaction. It is generally accepted that a bureaucratic and/or autocratic style of management 
hampers job satisfaction and can result in a staff member becoming alienated from his work (Theron, 1995:48; Litwin \& Stringer, 1968; Foa, 1976, as quoted by King \& Botha, 1997:113; Mullins, 1999:635). In 1986 already Barber (1986:28) argued that the supervisor as the leader could influence the personnel's level of job satisfaction. During King and Botha's (1997:114) empirical investigation it was confirmed that social workers place a high premium on good management of a welfare organisation as a prerequisite for job satisfaction.

\section{Group factors}

Barber (1986:28) and Theron (1995:29) state that the work group is of particular importance to the social worker because support from colleagues is indispensable in this profession. Kadushin (1992:278) has emphasised how essential it is to develop the trusting and supportive relationships in the work context to serve as a lifeboat, particularly during those very demanding days in the life of a social worker. Carrell et al. (1998:561) found that the quality of relationships in the work group is very important to personnel, particularly with regard to the extent to which they are accepted as part of the group and the friendliness and support that they receive from colleagues.

\section{Empirical findings with regard to the determinants of job satisfaction}

Respondents had to indicate certain organisational determinants that made an impact on their job satisfaction in their working environment (see Table 2). The variables were grouped as follows:

- Organisational variables (questions 1-20)

- Work content (questions 1-5)

- Remuneration (questions 6-7)

- Opportunities for promotion (questions 8-12)

- Working environment (questions 13-16)

- Leadership and management style (questions 17-20)

- Group factors (questions 21-22)

Social workers were also asked to prioritise three determinants from those listed in Table 2 which make the greatest contribution to increasing their job satisfaction. Eight (36\%) respondents gave highest priority to a fair and adequate remuneration package and fringe benefits as the variable which increases job satisfaction. The high priority assigned to remuneration is confirmed by King and Botha's (1997:111) research findings, namely that social workers no longer work simply for the sake of the cause. The following four determinants were given no priority:

- Opportunity to develop a variety of skills in all methods of social work

- Opportunity for work achievement

- Opportunity to perform a variety of tasks

- Opportunity to take calculated risks. 
TABLE 2

SOCIAL WORKERS' EXPERIENCE OF JOB SATISFACTION IN THEIR WORK SITUATION

\begin{tabular}{|c|c|c|c|c|c|c|c|}
\hline & \multirow[b]{2}{*}{ Aspects } & \multicolumn{2}{|c|}{ Yes } & \multicolumn{2}{|c|}{ No } & \multicolumn{2}{|c|}{ Incomplete } \\
\hline & & $\mathbf{f}$ & $\%$ & $\mathbf{f}$ & $\%$ & $\mathbf{f}$ & $\%$ \\
\hline 1 & $\begin{array}{l}\text { Opportunity to develop a variety of skills in all } \\
\text { methods of social work }\end{array}$ & 19 & 86 & 3 & 14 & 0 & 0 \\
\hline 2 & Opportunity for work achievement & 15 & 68 & 5 & 23 & 2 & 9 \\
\hline 3 & Opportunity to perform a variety of tasks & 22 & 100 & 0 & 0 & 0 & 0 \\
\hline 4 & Opportunity to be creative & 19 & 86 & 2 & 9 & 1 & 5 \\
\hline 5 & $\begin{array}{l}\text { Opportunity for challenging and meaningful } \\
\text { work }\end{array}$ & 17 & 77 & 5 & 23 & 0 & 0 \\
\hline 6 & $\begin{array}{l}\text { The remuneration package and fringe benefits are } \\
\text { adequate and fair }\end{array}$ & 2 & 9 & 20 & 91 & 0 & 0 \\
\hline 7 & Any form of reward for work well done & 6 & 27 & 16 & 73 & 0 & 0 \\
\hline 8 & Opportunity for new learning experiences & 20 & 91 & 1 & 4.5 & 1 & 4.5 \\
\hline 9 & Opportunity to grow and develop & 19 & 86 & 3 & 14 & 0 & 0 \\
\hline 10 & $\begin{array}{l}\text { New responsibilities as opportunities for } \\
\text { development with the view to promotion }\end{array}$ & 7 & 32 & 15 & 68 & 0 & 0 \\
\hline 11 & Availability of opportunities for promotion & 1 & 4.5 & 20 & 91 & 1 & 4.5 \\
\hline 12 & Opportunity for career development & 10 & 45 & 11 & 50 & 1 & 5 \\
\hline 13 & Equal opportunities, without discrimination & 15 & 68 & 7 & 32 & 0 & 0 \\
\hline 14 & Opportunity for work security & 10 & 45 & 11 & 50 & 1 & 5 \\
\hline 15 & Freedom to assert autonomy & 12 & 54 & 9 & 41 & 1 & 5 \\
\hline 16 & Opportunity to take calculated risks & 9 & 41 & 11 & 50 & 2 & 9 \\
\hline 17 & The supervisor provides support & 18 & 82 & 4 & 18 & 0 & 0 \\
\hline 18 & $\begin{array}{l}\text { Opportunity to give feedback about leadership } \\
\text { and management style }\end{array}$ & 5 & 23 & 17 & 77 & 0 & 0 \\
\hline 19 & $\begin{array}{l}\text { Opportunity to give feedback regarding general } \\
\text { management of the welfare organisation }\end{array}$ & 7 & 32 & 15 & 68 & 0 & 0 \\
\hline 20 & $\begin{array}{l}\text { Opportunity to give feedback about the quality of } \\
\text { supervision }\end{array}$ & 12 & 55 & 10 & 45 & 0 & 0 \\
\hline 21 & Colleagues offer support & 5 & 23 & 17 & 77 & 0 & 0 \\
\hline 22 & $\begin{array}{l}\text { Opportunity to experience and form group } \\
\text { loyalty }\end{array}$ & 15 & 68 & 6 & 27 & 1 & 5 \\
\hline
\end{tabular}

$\mathrm{n}=22$

\section{THE ROLE OF THE SUPERVISOR IN IMPROVING THE JOB SATISFACTION OF} GRASSROOTS SOCIAL WORKERS

In field practice supervision of social workers remains an integral part of the administrative structure and functioning of any welfare organisation and an inextricable part of service delivery to the client (Weinbach, 1990:7-11; Skidmore, 1995:245). Social work supervisors also have certain management tasks that can be used to address social workers' job satisfaction. Supervisors as managers can focus on creating and maintaining an optimal internal working environment, which promotes the delivery of effective services to all clients in the most efficient ways 
(Weinbach, 1990:7-11). The social work manager must act as a bridge between the social workers' individual expectations and the organisation's expectations, because grassroots social workers make decisions with their focus on individual clients and they do not focus on management functions.

Specific aspects in the task environment where the supervisor could have an influence include supervision, work content, the work group and giving recognition. These are discussed below.

\section{Supervision}

Responses to the question that respondents were asked, namely how can the supervisor contribute to increasing the social workers' job satisfaction, are provided in Table 3:

TABLE 3

SUPERVISORS CONTRIBUTION TO INCREASING THE SOCIAL WORKERS' JOB SATISFACTION

\begin{tabular}{|l|l|l|l|l|}
\hline & Yes & \multicolumn{2}{l|}{ No } \\
\hline Contributions & f & \% & f & \% \\
\hline Supportive contact & 21 & 95 & 1 & 5 \\
\hline Case conferences & 16 & 73 & 6 & 27 \\
\hline Manageable workload & 19 & 86 & 3 & 14 \\
\hline Group supervision & 18 & 82 & 4 & 18 \\
\hline Peer group supervision & 16 & 73 & 6 & 27 \\
\hline Feedback & 20 & 91 & 2 & 9 \\
\hline Creating a climate of trust & 22 & 100 & 0 & 0 \\
\hline Motivation & 21 & 95 & 1 & 5 \\
\hline Clarifying unclear policy and procedures & 21 & 95 & 1 & 5 \\
\hline Other & 3 & 14 & 0 & 0 \\
\hline
\end{tabular}

$\mathrm{n}=22$

Social workers' responses provide a clear indication to supervisors regarding those aspects that can and should be used to improve social workers' job satisfaction, because improved job satisfaction may possibly contribute to increased productivity and quality of outcomes-based services to the client.

\section{Work group}

The supervisor can render an input with regard to building the work group through the use of group supervision and promoting peer group supervision (Skidmore, 1995:249).

\section{Work milieu and work content}

A supervisor can, by ensuring a manageable workload, strengthen the job satisfaction of grassroots social workers. Managers and supervisors should also utilise organisational resources for promotion, financial rewards and improved working conditions so as to increase the levels of job satisfaction (Newsome \& Pillari, 1991:127). 


\section{Giving recognition}

Social work supervisors' role lies specifically in giving recognition that is not linked to remuneration. One of the greatest challenges of the supervisor is therefore to determine what personnel's needs are and to create a climate or environment in which these needs can be met. Carrell et al. (1998:501) are of the opinion that supervisors must be knowledgeable about the general techniques for motivating personnel.

An open question was posed to the respondents about what form of recognition social workers would like to receive from their supervisors. The majority of the respondents $(73 \%)$ preferred verbal recognition accompanied by a positive and friendly attitude. Recognition ought also to be given for strengths and initiatives taken.

\section{IMPROVING THE QUALITY OF WORK LIFE OF GRASSROOTS SOCIAL WORKERS}

In the literature the improvement of the quality of work life is indicated as the manner in which managers can increase the job satisfaction of their personnel. Lau and May (1998:213) mention that in the studies undertaken during the last decade a positive link was found between the quality of work life, the organisation's performance and growth, reduced absenteeism, a decrease in staff turnover and increased job satisfaction. The basic objectives of effective quality of work life programmes are indeed improved working conditions (from the personnel member's perspective) and increased organisational effectiveness (from the manager's perspective).

The reasoning behind improving the quality of work life is that people and organisations in modern society face rapid changes, which they have to adjust to for the sake of the job satisfaction of personnel (Coster, 1992:6; Mullins, 1999:630; Nel \& Van Dyk, 1998:237).

\section{Describing the concept: quality of work life $(Q W L)$}

Quality of work life is a multidimensional concept that has various meanings attached to it (Lau \& May, 1998:212). Terms used to describe this concept are co-responsibility for and increased staff participation in the organisation's objectives.

Snyman (1990:77) believes that the core factor in quality of work life deals with the person and his/her work and that which the manager can do for the personnel to create a climate in which they can be satisfied and motivated to perform. Ivancevich and Matteson (1990) as quoted by Anderson, Crous and Scheepers (1992:14) describe the working environment, which Snyman refers to, in far more detail when defining the quality of work life as a management philosophy which increases personnel's dignity and wellbeing through the introduction of changes into the culture of the organisation. The emphasis is therefore on the importance of the manager's willingness to change. Robbins (1998:354) provides a similar definition of the concept quality of work life, but adds that it increases the physical and mental health of personnel and in so doing creates an opportunity for growth and development

Cascio (1998:18) defines quality of work life as the personnel's perception of their physical and mental wellbeing at the workplace. Lau and May (1998:213) define quality of work life as favourable working conditions and an environment that increases job satisfaction by providing personnel with rewards, work security and opportunities for growth.

All the above-mentioned definitions focus on the culture in the organisation that offers personnel the opportunity to grow and develop. Quality of work life is therefore not only determined by the 
type of work (secretarial, cleaning or social work) that is done, but also by how the staff member is allowed to perform his/her tasks.

Cascio (1998:18) is of the opinion that there are two ways of looking at quality of work life. One perspective is to measure the quality of work life against a set of objective organisational conditions and working methods (e.g. policy regarding internal promotions, democratic supervision, staff involvement and a safe working environment). The other perspective equates the quality of work life with the personnel's concept of whether they are safe, experience relatively good satisfaction and are able to grow and develop as people. The latter perspective binds quality of work life to the extent to which the full spectrum of human needs is met. Cascio (1998:18) states that these two ways of looking at quality of work life are strongly linked to one another and irrespective of how they are looked at, both ways lead to a perception of an individual's quality of work life.

The core elements of the concept quality of work life that quite clearly emerge from all these definitions, are the following:

- Initiating change;

- Increasing the effectiveness of the organisation by means of participative management;

- Management philosophy;

- Willingness to enhance personnel's dignity by focusing on their physical and mental health;

- Creating opportunities for growth and development; and

- Increased effectiveness and productivity as a benefit for the organisation.

For the purposes of this research a combination of the components in the definitions of quality of work life provided by Lau and May (1998:213) and Gibson et al. (2000:150) will be used, namely, quality of work life is a management philosophy that enhances personnel's dignity through the creation of favourable working conditions, initiating changes in the culture of the organisation, improving the physical and emotional wellbeing of employees and creating opportunities for growth and development in an environment that promotes job satisfaction.

Gibson et al. (1997:354) challenge managers to revive and inspire their organisations by providing quality of work life and thereby achieve increased productivity, quality of service delivery and effectiveness.

\section{Components of importance in good quality of work life}

Nel and van Dyk (1998:241) are of the opinion that quality of work life impacts on all facets of the personnel's functioning in the organisation and that the efficient management and job satisfaction of personnel are of cardinal importance for a high quality of work life. If the administrator adopts a healthy approach to the quality of work life, the result will be increased satisfaction and performance on the part of personnel as a consequence of intrinsic motivation.

A healthy approach to quality of work life includes giving recognition to personnel, ensuring that work is interesting and that there is job satisfaction and growth in the work situation, and in particular that personnel's needs and values are addressed. The benefits that an organisation can expect as a result of having applied this approach is that the organisation will experience a low cost structure, personnel of a better quality, a decrease in staff turnover and lower daily absenteeism rates, job satisfaction and increased productivity. Personnel in an organisation such as this experience growth in the organisation, more participation in decision making, a feeling of self- 
actualisation, satisfaction, security and self-respect (Hian \& Einstein, 1990:18; Nel \& Van Dyk, 1998:241-242).

A few of the components of good quality of work life, each of which is rich in content, include:

- Remuneration package that includes intrinsic and extrinsic rewards that lead to general job satisfaction;

- Security and growth in the organisation which offers, among other things, the opportunity to learn new tasks and skills, the opportunity to do research and to use one's own initiative, as well as to build a career within the organisation (Nel \& Van Dyk, 1998:241);

- Taking into account the total living space that a balanced relationship between work (work schedules, career requirements, travel requirements) and the personnel's free time and family life imply (Cascio, 1998:25);

- Safe and healthy working conditions, which applies to the physical and mental working environment of personnel (Nel \& Van Dyk, 1998:241);

- A working environment in which the constitutional rights of personnel are upheld by ensuring that the following key elements in the working environment, necessary to establish a better quality of work life, are present:

- The personnel member's right to personal privacy;

- The personnel member's right to freedom of speech;

- The personnel member's right to equitable treatment;

- Work procedures that imply control and regulation of laws and regulations (Cascio, 1998:18; Gordon, 1983 as quoted in Snyman, 1990:85);

- Social integration or socialising in the organisation, which implies that opportunities are provided for social interaction with other staff members and equal opportunities for maintaining good personal relationships and treatment without racial or gender bias.

TABLE 4

COMPONENTS OF IMPORTANCE FOR GOOD QUALITY OF WORK LIFE

\begin{tabular}{|l|l|l|l|l|}
\hline Components & \multicolumn{2}{l|}{ Agree } & \multicolumn{2}{l|}{ Disagree } \\
\hline & f & \% & f & \% \\
\hline Satisfaction with the remuneration package & 16 & 73 & 6 & 27 \\
\hline Security and growth in the organisation & 17 & 77 & 5 & 23 \\
\hline A balanced relationship between work and family life & 20 & 91 & 2 & 9 \\
\hline Safe and healthy working conditions & 20 & 91 & 2 & 9 \\
\hline The protection of personnel's rights & & & & \\
\hline The development of human resources takes place & 19 & 86 & 3 & 14 \\
\hline $\begin{array}{l}\text { The workplace provides the opportunity for social integration/- } \\
\text { interaction of personnel }\end{array}$ & 20 & 91 & 2 & 9 \\
\hline
\end{tabular}

$\mathrm{n}=22$ 


\section{Empirical findings with regard to the components that are of importance in good quality of work life}

Social workers were asked to indicate if the above-mentioned components are important to them regarding good quality of work life. Their responses are presented in Table 4.

The components of good quality of work life are generally not discussed in the literature on social work management. All the above-mentioned components regarding quality of work life are regarded as important for good quality of work life by $73 \%$ to $100 \%$ of the respondents.

\section{Programmes for the improvement of quality of work life}

Programmes to improve the quality of work life are implemented to benefit both the organisation and the social worker. Currently it appears that although each organisation that has started a quality of work life programme has developed its own structure, traditions and approach towards it, there are certain basic elements that should be present, such as:

- A committee that serves as a bridge between the trade union and management;

- Agreements regarding the boundaries of the programme that allow both parties, namely personnel and management, to feel safe;

- Objectives jointly determined and ratified and then made known;

- Training programmes developed for all participants and areas requiring change are identified; and

- A third party facilitator to help with defining objectives, providing training and facilitation of group processes.

Quality or work life programmes are regarded as a positive way to build relationships between trade unions and managers and are of particular importance for improving the general working conditions and increasing the wellbeing of personnel (Lawler, 1992:298). The current interest in quality of work life is based on the expectation that work should be more meaningful, that personnel's personal skills should be developed, that they should participate in the management process and that any system should exert voluntary instead of compulsory control. Eight methods that can be followed in the process, are:

1. Teamwork;

2. Participative management;

3. In-service training and personnel development;

4. Career development;

5. Job design and job enrichment;

6. Sensitivity training;

7. Quality circles (small groups of social workers who meet regularly with their supervisors to identify the quality of service and problems regarding quality of work life and to take corrective actions) (McKenna, 1994:372);

8. Management by objectives. 


\section{Empirical findings regarding programmes for the improvement of quality of work life}

The respondents (social workers) had to indicate which programmes they believed would make the greatest contribution to the improvement of quality of work life in the organisation. These responses are provided in Table 5.

TABLE 5

PROGRAMMES THAT OUGHT TO BE USED FOR THE IMPROVEMENT OF THE QUALITY OF WORK LIFE

\begin{tabular}{|l|l|c|c|}
\hline Choice & Programmes & f & \% \\
\hline 1 & Participative management & 14 & 64 \\
\hline 2 & Sensitivity training & 14 & 64 \\
\hline 3 & Management by objectives & 13 & 59 \\
\hline 3 & Teamwork & 11 & 50 \\
\hline 4 & Career development & 10 & 45 \\
\hline 4 & Quality circles & 10 & 45 \\
\hline 5 & Job enrichment & 9 & 41 \\
\hline 6 & In-service training and personnel development & 8 & 36 \\
\hline 7 & Job design & 7 & 31 \\
\hline
\end{tabular}

1. $\mathrm{n}=22$

2. Respondents could select more than one response.

Most respondents (64\%) indicated that participative management and sensitivity training are their first choice of programmes for the increase of quality of work life. It is quite significant that sensitivity training is so highly valued in a profession that is in itself person orientated.

\section{CONCLUSIONS AND RECOMMENDATIONS}

\section{Determinants of job satisfaction}

Work content is positively experienced by the respondents. This includes the opportunity to perform meaningful work, to be creative and to utilise a variety of tasks and skills.

- In the light of the high premium that is also placed on this aspect of work content in King and Botha's (1997:109) research, it is recommended that managers and supervisors continually monitor and enhance work content, particularly during decision making.

Respondents give the highest priority to adequate and fair remuneration packages and benefits as a variable for increasing job satisfaction and this also features in respondents' definition of job satisfaction.

- Measurement can possibly be used to determine what social workers regard as a fair and reasonable remuneration package, so that ways can be found to address this need - for example using alternative sources of funding or new budgeting strategies. 
Social workers attach the greatest value to verbal recognition accompanied by a friendly and positive attitude, sincere appreciation, acknowledgement of strengths and initiative taken. Constructive criticism with regard to insufficient growth or stagnation is valuable.

- The utilisation and development of systems for providing recognition ought to receive attention. Because the need for recognition appears to be a highly individual matter, it is recommended that managers and supervisors, firstly, formulate policy regarding appropriate forms of recognition for their specific welfare organisation and, secondly, determine what would be appropriate for individual social workers.

According to the social workers' responses, supervisors can contribute towards increasing social workers' job satisfaction in the following ways:

- Feedback;

- Creating a climate of trust;

- Motivation;

- Clarifying unclear policy and procedures; and

- Supportive contact.

Psychometric tests could be used for future research regarding specific determinants of social workers' job satisfaction.

The Science Research Associates Attitude Survey includes dimensions of job satisfaction; Morse's job satisfaction index tests the intrinsic aspects of job satisfaction and Brayfield and Rothe's job satisfaction index concentrates specifically on intensity of feelings (Miller, 1991:449-468).

\section{Components of a good quality of work life}

Components of a good quality of work life as described in the literature on Business Economics can be linked to social workers' job satisfaction needs. These include remuneration, security, safe and healthy working conditions, the protection of employee rights, the development of human resources and the opportunity for social integration.

- Managers and supervisors ought to examine the components of good quality of work life further and consciously apply them so as to make welfare organisations better workplaces in this highly competitive market.

The literature on the subjects of Business Economics and Management contains valuable information regarding the creation of quality of work life that can be used by social work managers in the formulation of policy and strategies to improve job satisfaction.

\section{Programmes for the improvement of quality of work life}

The respondents indicated that apart from in-service training and personnel development, the other programmes such as teamwork, participative management, career development, job design and job enrichment, sensitivity training and quality circles, have not been fully used to improve the quality of work life and in so doing increase job satisfaction.

- It is recommended that in particular the rationale, nature and purpose of programmes such as participative management, sensitivity training, management by objectives and teamwork be studied in depth by managers and supervisors. This will contribute to well thought-through decisions being taken with a view to goal achievement, implementation and application of 
programmes as well as periodic evaluation of the programmes. This recommendation also implies that decisions must be taken about who will facilitate the implementation of the programme(s) and how personnel are to be trained for this.

\section{REFERENCES}

ANDERSON, D.R.; CROUS, F. \& SCHEEPERS, J.M. 1992. Flow and quality of work life in a diverse workforce. Journal of Industrial Psychology, 22(3):13-20.

ARCHES, J.1991. Social structure, burnout and job satisfaction. Social Work, 36(3):202-206.

BARBER, G. 1986. Correlates of job satisfaction among human service workers. Administration in Social Work, 10(1):25-38.

BUTLER, B.B. 1990. Job satisfaction: management's continuing challenge. Social Work, Journal of the National Association of Social Workers, 35(2):112-117.

CARRELL, M.R.; ELBERT, N.F.; HATFIELD, R.D. GROBLER, P.A.; MARX, M. \& VAN DER SCHYF, S. 1998. Human resource management. Cape Town: Prentice-Hall.

CASCIO, W.F. 1998. Managing human resource. Productivity, quality of work life, profits. ( $5^{\text {th }}$ ed) Boston: McGraw-Hill.

CONRADIE, F.W. 1990. 'n Bedryfsielkundige ondersoek na die invloed van organisasieklimaat op werkstevredenheid in die openbare sektor. Ongepubliseerde magisterverhandeling, Universiteit van Stellenbosch.

CONWAY, P.G.; WILLIAMS, M.S. \& GREEN, J.L. 1987. A model of job satisfaction. Journal of Social Work Education, Winter 23(1):48-57.

COSTER, E,A. 1992. The perceived quality of working life and job facet satisfaction. Journal of Industrial Psychology, 18(2):6-9.

GERBER, P.D. 1998. Menslikehulpbronbeplanning, In: GERBER, P.D.; NEL, P.S. \& VAN DYK, P.S. Menslikehulpbronbestuur. 1998 ( $4^{\text {de }}$ uitg) Halfweghuis: Thompson Publishing.

GIBSON, J.L.; IVANCEVICH, J.M. \& DONNELLY, J.H. 1997. Organizations. Behavior, structure, processes. $\left(9^{\text {th }}\right.$ ed $)$ Chicago: Irwin.

GIBSON, J.L.; IVANCEVICH, J.M. \& DONNELLY, J.H. 2000. Organizations. Behavior, structure, processes. $\left(10^{\text {th }}\right.$ ed) Chicago: Irwin.

GORDON, J.R. 1993. A diagnostic approach to organizational behavior. Boston, Massachusetts: Allyn \& Bacon.

GRUNEBERG, M. 1979. Understanding job satisfaction. New York: John Wiley \& Sons.

HANDWOORDEBOEK VAN DIE AFRIKAANSE TAAL. 1994. S.v. "Spanwerk". Midrand: Perskor.

HAYNES, K.S. 1979. Job satisfaction of mid-management social workers. Administration in Social Work, 3(2):207-217.

HIAN, C.C. \& EINSTEIN, W.O. 1990. Quality of work life (QWL): What can unions do? SAM Advanced Management Journal, Spring:17-22.

JAYARATNE, S. \& CHESS, W. 1984. Job satisfaction, burnout, \& turnover: A national study. Social Work, 29(5):448-452. 
KADUSHIN, A. 1992. Supervision in social work. $\left(3^{\text {rd }}\right.$ ed) New York: Columbia University Press.

KING, A. \& BOTHA, A. 1997. Die organisatoriese determinante van beroepsbevrediging in maatskaplike werk. Die Maatskaplikewerk-Navorser-Praktisyn, 10(2):107-119.

LAU, R.S.M. \& MAY, B.E. 1998. A win-win paradigm for quality of work life and business performance. Human Resource Development Quarterly, 9(3):211-226.

LAWLER, E.E. 1992. The ultimate advantage. San Francisco: Jossey-Bass.

MCKENNA, E. 1994. Business psychology and organisational behaviour. Hove, East Sussex: Lawrence Erlbaum Associates.

MILLER, D.C. 1991. Handbook of research design and social measure. $\left(5^{\text {th }}\right.$ ed) Newbury Park, California: Sage.

MOUTON, J.; MARAIS, H.C. \& MEDEWERKERS. 1989. Metodologie van die geesteswetenskappe. Pretoria: J.C. Insto-Print.

MULLINS, L. 1999. Management and organisational behavior. $\left(5^{\text {th }}\right.$ ed) London: Pitman.

NEL, P.S. 1998. Loopbaanbestuur, In: GERBER, P.D.; NEL, P.S. \& VAN DYK, P.S. Menslikehulpbronbestuur. ( ${ }^{\mathrm{de}}$ uitg). Halfweghuis: Thompson Publishing.

NEL, P.S. \& VAN DYK, P.S. 1998. Gehalte van die werkslewe en sosiale verantwoordelikheid, In: GERBER, P.D.; NEL, P.S. \& VAN DYK, P.S. Menslikehulpbronbestuur. (4 ${ }^{\text {de }}$ uitg) Halfweghuis: Thompson Publishing.

NEWSOME, M. \& PILLARI, V. 1991. Job satisfaction and the worker-supervisor relationship. The Clinical Supervisor, 9(2):119-129.

POULIN, J.E. 1995. Job satisfaction of social work supervisors and administrators. Administrators in Social Work, 19(4):35-49.

POULIN, J.E. \& WALTER, C. 1992. Retention plans and job satisfaction of gerontological social workers. Journal of Gerontological Social Work, 19(1):99-114.

ROBBINS, S.P. 1998. Organizational behaviour. $\left(8^{\text {th }}\right.$ ed) New Jersey: Prentice-Hall.

SILVER, P.T.; POULIN, J.E. \& MANNING, R.C. 1997. Surviving the bureaucracy: The predictors of job satisfaction for the public agency supervisor. The Clinical Supervisor, 15(1):120.

SKIDMORE, R.A. 1995. Social work administration. Dynamic management and human relationships. ( $3^{\text {rd }}$ ed) Boston: Allyn and Bacon.

SKIDMORE, R.A.; THACKERAY, M.G. \& FARLEY, O.W. 1997. Introduction to social work. $\left(7^{\text {th }}\right.$ ed) Boston: Allyn and Bacon.

SNYMAN, C.M. 1990. Die rol van bestuur in die verbetering van werklewegehalte en produktiwiteit. Ongepubliseerde magisterverhandeling, Universiteit van Pretoria.

SUID-AFRIKA. 1995. Wet op Arbeidsverhoudinge, no.66, 1995. Pretoria: Staatsdrukker.

SUID-AFRIKA. 1997. Wet op Basiese Diensvoorwaardes, no.75, 1997. Pretoria: Staatsdrukker.

THERON, L.F. 1995. Die rol van supervisie ten opsigte van die werksbevrediging van 
maatskaplike werkers. Stellenbosch: Universiteit van Stellenbosch. (Ongepubliseerde magisterverhandeling)

VAN DER WESTHUIZEN, P.C.; WISSING, M.P.; HILLEBRAND, I.H. 1992. Werksbevrediging by die onderwyser. Tydskrif vir Geesteswetenskappe, 32(1):40-51.

VAN NIEKERK, C.H. 1994. Werkstevredenheid by spesialiste aan die fakulteit van geneesskunde, Universiteit van die Oranje-Vrystaat. Stellenbosch: Universiteit van Stellenbosch. (Ongepubliseerde magisterverhandeling)

VINOKUR-KAPLAN, D.; JAYARENTNE, S. \& CHESS, W.A. 1994. Job satisfaction and retention of social workers in public agencies, non-profit agencies, and private practice: The impact of workplace conditions and motivators. Administration in Social Work, 18(3):93-121.

WEINBACH, R.W. 1990. The social worker as manager: Theory and practice. New York: Longman.

WIESNER, R. \& VERMEULEN, L.P. 1997. Revised job design practices for future South African organisations. South African Journal of Economics and Management Science, 21:175-196. 